\title{
Kütüphanecilik ve Bilgi Yönetimi Literatüründe Kullanıcı
}

Users in Literature of Librarianship and Information Management

\section{Nazan ÖZENÇ UÇAK}

\section{Öz}

Bu çalışmada Türkiye'de kütüphanecilik ve bilgi yönetimi alanlarında kullanıcılar konusunda yapılan tez ve makaleler incelenmiştir. Bu amaçla yüksek lisans ve doktora tezleri ile alanın önemli süreli yayınları olan Türk Kütüphaneciler Derneği Bülteni (1952-1986), Türk Kütüphaneciliği (1987-2006) ve Bilgi Dünyası (2000-2006) dergilerinde yayımlanan makaleler araştırılmıştır. Incelenen 239 tezin 42'sinde $(\% 17,57)$ ve 1788 makalenin 44 'ünde $(\% 2,4)$ kullanıcılara doğrudan veya dolaylı olarak yer verildiği saptanmıştır. Tezlerin \%88'i (42 tez) 1990 sonrasında yapılmıştır. İçerik analizi sonuçlarına göre tezlerin \%69'unda kullanıcıların bir bilgi merkezi veya sistemiyle ilişkilendirildiği; \%83'ünde betimleme yönteminin kullanıldığı; anketin en sık kullanılan veri toplama tekniği olduğu ve araştırmaların akademisyenler üzerinde yoğunlaştığı anlaşılmaktadır. Makalelerde ise 1971 yılına kadar kullanıcı faktörünün incelenmediği, 1980'li yıllarda bu konuya gösterilen ilginin nispeten arttığı, 1990 sonrasında ise ilgili makale sayısında büyük bir artış olduğu görülmektedir. Makalelerde en sık (\%40) araştırılan kullanıcı grubunun öğrenciler olduğu; ağırıkla bilgi okuryazarlığı ve okuma alışkanlığı konularına değinildiği; betimleme yöntemi ile

\footnotetext{
“ Bu makale "Değişen Dünyada Bilgi Yönetimi Sempozyumu, 24-26 Ekim 2007, Ankara.” da bildiri olarak sunulmuştur.

"Doç.Dr.; Hacettepe Üniversitesi Bilgi ve Belge Yönetimi Bölümü, 06800 Beytepe, Ankara (ucak@hacettepe.edu.tr)
} 
anket ve görüşme tekniklerinin en sık tercih edilen yöntem ve veri toplama teknikleri olduğu anlaşılmaktadır.

Anahtar sözcükler: Kullanııılar, Kullanıcı araştırmaları-Türkiye, Bilgi Dünyası, Türk Kütüphaneciliği, Türk Kütüphaneciler Derneği Bülteni.

\begin{abstract}
In this paper, theses and articles on librarianship and information management focusing on users are studied. Masters and PhD theses along with articles published in the most important periodicals of the field, Türk Kütüphaneciler Derneği Bülteni (19521986), Türk Kütüphaneciliği (1987-2006) and Bilgi Dünyası (20002006), are examined. Some 42 out of 239 theses (17.57\%) and 44 out of 1788 articles (2.4\%) focused on users either directly or indirectly. The majority of such theses (88\%) were written after 1990. Content analysis of theses indicates that users have been studied primarily in relation with an information center or system (69\%); academicians as a user group was studied most often; survey as a research method was used in $83 \%$ of the theses; and, the questionnaire was the most popular data gathering technique. Although no articles emphasizing the users were published before 1971, a growing interest towards the users was detected in 1980s. The number of articles published on the subject significantly increased after 1990. Also, findings on articles indicate that students were the most frequently surveyed user group (40\%); subjects such as information literacy and reading habits were studied the most while surveys, questionnaires and interviews were the most popular research methods and data collection techniques.
\end{abstract}

Keywords: Users, User studies-Turkey, Information World, Journal of the Turkish Librarianship, Journal of the Turkish Library Association.

\title{
Giriş
}

Bilgi yönetimi ve kütüphaneciliğin temel felsefesi bilgi ile bireyleri buluşturabilmektir. Bu nedenledir ki bilgi sağlanır, düzenlenir ve sunulur. Bütün bu süreç ve bu süreç içinde gerçekleştirilen çalışmalar ve kullanılan araçlar bilim dalımızın kapsamı içine giren işlerdir. Ancak bu süreç, yapılan işler ve araçlar çoğu kez bunları kimin için yaptığımızı düşünmeden, sadece yaptığımız işe 
yoğunlaşarak geçmektedir. İşte bu noktada, bütün bu uğraşın kimin için olduğu sorusunu yanıtlamamızda ve elde ettiğimiz bulgularla daha iyi hizmetler tasarlayabilmemizde bize yardımcı olan kullanıcı araştırmalarıdır. Harrod's Librarians' Glossary'de kullanıcı araştırmaları (user studies) "kullanıcıların bilgi hizmetlerinden ne bekledikleri, nasıl bilgi aradıkları, var olan hizmetlerin intiyacı karşılayıp karşılamadığı ve amaca göre en iyi hizmetlerin nasıl tasarlanacağının ve geliştirileceğinin betimleme veya anketlerle saptandığı araştırmalardır" (Prytherch, 1995) şeklinde tanımlanmaktadır. Ancak bu tanımın, bugün için yetersiz ve araştırmaları belli yöntemlerle sınırlandırması açısından ise hatalı olduğunu söyleyebiliriz. Kullanıcı araştırmaları bireylerin bilgi ile iliş̧isini içeren tüm konuları kapsamaktadır. Bu konuları sadece bilgi merkezleri ile ilişkilendirerek ele almak bugünün bilgi ortamı için geçerli değildir. Bilgi intiyacı, bunun ifade edilişi, bilgi arama ve kullanma özellikleri bunları etkileyen nedenler, bilginin zihinde işlenişi ve bütün bunların bireylere göre gösterdiği farklılıklar kullanıcı araştırmalarının konusunu oluşturmaktadır. Literatürde kullanıcı araştırmasından çok "bilgi gereksinimi", "bilgi arama davranışı" ve "bilgi kullanımı" sözcükleri altında eriştiğimiz bu çalışmalar, Wilson'ın (1981) bu kavramları birbirine etkisini de dikkate alarak tek bir başlık altında toplamasından bu yana, "bilgi davranışı" (information behavior) başığıyla da sıkça karşımıza çıkmaktadır.

Kullanıcı araştırmaları var olan sistemleri, hizmetleri değerlendirmek açısından önemli olduğu kadar; insanın bilgiyle olan ilişkisini, içsel süreçleri, bilgiyle ilgili davranışların nedenlerini anlamak açısından da önemlidir. Bu çalışmalar sonucu elde edilen bulgular etkili hizmet ve sistemlerin tasarlanabilmesi için gereklidir. Bilgi hizmetlerinin giderek elektronik ortama kaydığı günümüz iletişim ortamında bu verilerin önemi daha çok anlaşılmaktadır. Kullanıcının bilgi ile olan ilişkisi içinde bulunulan toplum, çalışma ortamı ve bilgi sistemleri gibi pek çok unsurdan etkilenmektedir. Bu nedenle kullanıcının çevresi ile ele alınması gereği, her toplumun kendi kullanıcı profilini ortaya çıkarması için bu araştırmalara ağırlık vermesini gerektirmektedir. 
$\mathrm{Bu}$ bildirinin amacı, kullanıcı araştırmalarının bilgi yönetimi için önemine dikkat çekmek ve Türkiye'de kütüphanecilik ve bilgi yönetimi literatüründe yer alan kullanıcı ile ilgili yazıları değerlendirmektir.

\section{Kullanıcı Araştırmalarının Dünya Literatüründeki Yeri ve Gelişimi}

Kullanıcı araştırmalarının başlangıç tarihi ile ilgili farklı yaklaşımlar vardır. Case'in (2002) Poole'a (1985) dayanarak belirttiği gibi, kullanıcı araştırmalarının başlangıç tarihini 1902 yılında Charles Eliot'ın kütüphane koleksiyonlarının kullanılma oranlarını araştırdığı yazısına kadar dayandıran araştırmacılar vardır. Bouazza (1989) kullanıcı araştırmalarını farklı yönleriyle tanıttığı yazısında bu çalışmaların başlangıç tarihini 1920'li yıllar olarak göstermektedir. Wilson (2000) 1948 yılında toplanan "Royal Society Scientific Information Conference"ın yaptığı çalışmaların kullanıcı araştırmaları için başlangıç oluşturduğunu, bu çalışmaların 1958 yılında "International Conference on Scientific Information"da yeniden ele alındığını, ancak bu çalışmaların ciddi sonuçlara ulaşmadığı yönünde genel bir fikir birliğinin olduğunu belirtmektedir. 1950 ile 1960 yılları arasında yapılan çalışmalarda, daha çok temel ve uygulamalı bilimler alanında çalışan kullanıcılar ele alınmış ve genelde bu kullanıcıların materyal kullanım özellikleri incelenmiştir. 1966 yılında Annual Review of Information Science and Technology (ARIST) adlı yıllığın bilgi gereksinimi ve kullanımıyla ilgili yayınları ve bunlara ilişkin değerlendirmeleri vermeye başlamasıyla birlikte, bu alandaki literatürün takibi kolaylaşmıştır. Bu dönemde Menzel (1966) ve Paisley (1968) tarafından 1960 öncesi yapılan kullanıcı araştırmaları değerlendirilerek, bu çalışmaların yüzeysel nitelikte oldukları ve elde edilen bulguların pek çok açıdan birbiriyle karşılaştırılabilir özellikte olmadığı sonuçlarına ulaşıımıştır. Ayrıca bu dönemde yapılan çalışmaların kullanıcıların bilgi gereksinimi ve kullanımını tanımlamada yetersiz kaldığı ve bu konuda yaklaşım ve yöntem de dâhil olmak üzere yeni bakış açılarına intiyaç olduğu dile getirilmiştir. Bu değerlendirmeler konuyla ilgili sorunların ilk kez dile getirilmesi açısından olduğu kadar, 1960 öncesi araştırmaları anlamamızda da önemlidir. 
ARIST kullanıcı araştırmalarına erişimde önemli bir kaynak olmasına rağmen, bu kaynakta genelde "bilgi gereksinimi ve kullanımı" (Information needs and uses) başlığı altında yer alan değerlendirme yazıları bazen değerlendirmeyi yapan yazarın ilgi alanına göre konunun belli bir kısmıyla (fen ve teknik bilim kulanıcıları, yöntem gibi) sınırlı kalmış, çoğu kez de kesintiye uğramıştır. Buna rağmen $A R I S T$ te yer alan değerlendirme yazılarına ve atıflara bakarak 1960 sonrası kullanıcı araştırmalarının sayısının giderek artığını söyleyebiliriz. 1966-1990 yılları arasında yayımlanan toplam 11 değerlendirme yazısında yıllık ortalama 67 araştırma olmak üzere yüzlerce çalışma tanıtılmıştır. Bunlara iki bibliyografik makale de eklenecek olursa bu süre içinde 13 makalede toplam 1998 yayına atıf yapıldığı anlaşılmaktadır (Case, 2002).

Bu konudaki literatürün sayısal gelişimi hakkında bilgi veren başka çalışmalar da vardır. Bunlardan bir tanesi de Bates'in (2000) hazırlamış olduğu bilgi arama, indeksleme ve bilgi erişim sistemleri tasarımı ile ilgili bibliyografyadır. Bu bibliyografyada yer alan dokuz başlıktan bir tanesi de bilgi arama davranışıdır. Bu başlık altında Bates yedi alt başlık açarak her başlık altında o konuda olan yayınları listelemiştir. Bu yayınlar arasında birkaç kitap ve rapor da yer almaktadır. Bu başlıklar altında 585 yayın listelenmiştir (bilgi arama - genel, teorik: 74, bilgi arama - halk, çocuklar, öğrenciler: 129 , bilgi arama - doğa ve sosyal bilimler: 55 , bilgi arama - sanat ve insani bilimler: 159, bilgi arama - meslekler ve sanayi: 59, bilgi arama - kütüphane ve bilgi hizmetlerinin kullanımı: 97 ve okuryazarlık: 12). Case'in (2002) bilgi gereksinimi, bilgi arama ve davranışlarıyla ilgili araştırmaları betimlediği çalışmasında ise konuyla ilgili 738 yayına atıf yapıldığı görülmektedir.

Kullanıcı araştırmalarıyla ilgili gelişmelerin ancak bu alandaki literatürün çok yönlü irdelenmesiyle saptanabileceğini savunan Julien (2000), Library Literature'da "kullanıcı araştırmaları" ve "bilgi gereksinimi" başlıkları altında yer alan bine yakın makaleyi yazar, yayın, kullanıcı grubu, yöntem, yapılan atıflar gibi pek çok özelliği dikkate alarak çok yönlü olarak incelemiştir. 1984-1998 yılları arasında yayımlanan makaleleri değerlendiren Julien (2000) bu makalelerin \%45'inde konunun bir sistemle ilişkili olarak ele 
alındığını, daha çok öğrencilerin, akademisyenlerin ve belli meslek gruplarına bağlı kullanıcıların incelendiğini saptamıştır. İncelenen araştırmaların büyük bir kısmının nicel yöntemlerle gerçekleştirildiği, en fazla anket ve görüşme teknikleri ile veri toplandığı elde edilen bulgulardan anlaşılmaktadır. Ayrıca Julien (2000), makalelerde bilgibilim ve kütüphanecilik alanına ve bu alan dışındaki bilim dallarına yapılan atıfları incelemiştir. Çalışmalarda alan dışına yapılan atıflarda artış olması, kullanıcı araştırmalarının giderek daha çok disiplinler arası bir biçimde ele alındığını göstermesi açısından önemli bulunmuştur.

Literatürde kütüphanecilik ve bilgibilim literatürünü genel olarak ele alıp, çalışma konularının oranlarını veren araştırmalar da vardır. Bu araştırmalar genel literatür içinde kullanıcı ile ilgili olan yayınların oranını anlamak açısından yardımcıdır. Jarvelin ve Vakkari'nin (1990) yapmış oldukları araştırmaya göre kütüphanecilik ve bilgibilim literatürünün \%8'ini bilgi gereksinimi ve kullanımı konusunda yapılan araştırmalar oluşturmaktadır. Ancak bu konularda yapılan araştırmaların 1990 sonrası hızla artığı dikkate alınacak olursa bugün bu oranın daha fazla olduğu söylenebilir.

Kullanıcı araştırmalarını nitelik olarak değerlendirdiğimizde, bu çalışmaları iki grup altında toplamak gerektiği anlaşılmaktadır. Başlangıcından 1980'li yıllara kadar olan çalışmalarda kullanıcı anlayışının bir bilgi merkezini kullanan aktif kullanıcı ile sınırlı olduğu, araştırmaların sistem merkezli tasarlandığı ve genelde "ne" sorusuna yanıt arandığı ve bu nedenle de nicel yöntemlere ağırlık verildiğini görüyoruz. 1980 sonrası yapılan araştırmaların ise kullanıcıyı bir bilgi merkezi ile ilişkilendirmeden doğal çevresi içinde ele alan kullanıcı merkezli çalışmalar olduğunu söyleyebiliriz. Nitekim bu tarihten sonra kullanıcı ve kullanıcı araştırmalarının kapsamına bakış büyük ölçüde değişmiştir. Kullanıcılar bilgi merkezlerini bizzat kullanan aktif kullanıcıların yanı sıra pasif kullanıcılardır. Bu dönemden sonra kullanıcının birey olarak ele alınması, bilgi gereksinimi, bilgi arama, bilgi kullanma davranışları ve bunları etkileyen unsurlar üzerinde yoğunlaşılmaya başlanmıştır. 1990 sonrasında ise özellikle Internet'in yaygın kullanımının etkisiyle birlikte bilgi sistemlerinin 
kullanıcı özellik ve beklentilerine göre tasarlanması gereği bu çalışmaların önemini artırmıştır. Bu durum araştırma sayısını ve niteliğini yükseltirken, yapılan araştırmaların uygulamaya aktarımında yaşanan sorunlara daha çok dikkat çekilmesine neden olmuştur. Araştırmalarda, var olan durumun tekrar tekrar betimlenmesinden kurtulup, nedenleri saptamak amacıyla sosyal bilimlerin farklı alanlarında kullanılan nitel yöntemlerden yararlanımasına, alanın kuram ve modellerinin geliştirilmesine son yirmi yıl içinde daha çok ağılık verilmiştir.

\section{Türkiye'de Konuyla İlgili Çalışmalar}

Türkiye'de kullanıcı araştırmaları üzerine ilk değerlendirme Çapar (1990) tarafından yapılmıştır. Çapar makalesinde ülkelerin bilgi politikalarının oluşturulmasında kullanıcı araştırmalarının önemine değindikten sonra, bu tarihe kadar yapılan kullanıcı araştırmalarının sayısının yetersizliğine dikkat çekmektedir. Bu tarihten sonra Uçak'ın 2001 ve 2004 yıllarında yaptığı çalışmalarda kullanıcı araştırmalarının sorunlarını ele alıp incelediği ve kullanıcı araştırması içeren tezleri değerlendirdiği görülmektedir. Ancak bu çalışmaların ülkemizde yapılan kullanıcı araştırmalarının bütününü vermediği açıktır.

Türk kütüphaneciliği ve bilgi yönetimini değerlendiren yazılar incelendiğinde, kullanıcı araştırmalarının literatürümüzdeki yeri hakkında dolaylı da olsa bir fikir edinmek mümkündür. Bu konuda yapılan çalışmalara kısaca bir göz atacak olursak; literatürü değerlendiren ilk yazının Adnan Ötüken'e ait olduğunu görürüz. Ötüken (1961) tarafından ilk mesleki dergimiz olan Türk Kütüphaneciler Derneği Bülteni'nin (TKDB) on yıllık kapsamı bir indeks denemesi ile değerlendirilmiştir. $\mathrm{Bu}$ değerlendirme kapsamında belirlenen konu başlıkları içinde "kullanıcı" veya "okuyucu" başlığının yer almadığı görülmektedir Ötüken tarafından saptanan konu başlıkları şu şekildedir: Amerikan kütüphaneleri; bibliyografya ve dokümantasyon meseleleri; çocuk kütüphaneleri; gezici kütüphaneler; halk kütüphaneleri; İran kütüphaneleri; kanunlar, tüzükler, yönetmelikler; kitaba, kitaplara, okumaya dair; kütüphanecilik öğretimi ve eğitimi; kütüphanecilik tekniği; Millî Kütüphane; okul kütüphaneleri; şahıs bibliyografyaları; Türk 
kütüphaneciliğine hizmet edenler; üniversite kütüphaneleri (Ötüken, 1961, s. 164-165). Bu sınıflamadan da anlaşılacağı gibi derginin ilk on yıllık yayın hayatında kütüphane türleri, kütüphanecilik eğitimi ve işlemleri konuları ağırlık kazanırken, bu süre içinde kullanıcı ile ilgili hiç bir yazı yayımlanmamıştır.

Türk kütüphanecilik literatürünü süreli yayınlar açısından değerlendiren ikinci çalışma, Yontar ve Yalvaç (2000) tarafından 1952-1994 yılları arasında yayımlanan makaleleri konu ve yöntem açısından inceleyen araştırmadır. Bu araştırmaya göre bu dönem içinde süreli yayınlarda en fazla yer alan konu "kütüphane" ve "bilgi hizmetleri" konularıdır. Bunları "kütüphane yönetimi", "bibliyografya", "kataloglama ve sınıflama" konuları izlemektedir. Araştırma sonucuna göre bu dönemde üzerinde en az çalışılan konu "kullanıcılar"dır.

Mesleki literatürümüzü değerlendiren bir diğer önemli araştırma Tonta'ya (2002) aittir. Tonta, 1987-2001 yılları arasında Türk Kütüphaneciliği dergisinde yayımlanan 238 makaleyi bibliyometrik özellikler açısından incelemiştir. Dergide yer alan makalelerin konuları 25 başlık altında gruplandırımıştır. Bu sınıflamaya göre 238 makalenin 51'i (\%21) "kütüphaneler", 29'u (\%12) "bibliyografik denetim", 19'u (\%8) "bilgi teknolojisi”, 15’i (\%6) "bilgi kaynakları" konusundadır. İncelenen 238 makalenin sadece 4 tanesi $(\% 1,7)$ "kullanıcı ve bilgi kullanımı" ile ilgilidir.

Yontar'ın (1995) 1958-1994 yılları arasında kütüphanecilik bölümlerinde yapılan lisansüstü tezleri konularına göre incelediği yazısı ise, bize bu dönemde yapılan tez konuları hakkında bir ipucu vermektedir. Bu araştırmaya göre 1958-1994 yılları arasında "kütüphane ve bilgi hizmetleri" \%50,9 ile en çok araştırılan konu olurken, "bilgi arama davranışları" en az incelenen tez konusu olmuştur.

Belli dönemlerde genel olarak kütüphanecilik ve bilgi yönetimini değerlendiren bu araştırmalar, alanımızda yapılan araştırma konuları hakkında bilgi vermekle birlikte, literatürümüzde yer alan kullanıcı araştırmalarını bir bütün olarak yansıtmamaktadır. 


\section{Yöntem}

$\mathrm{Bu}$ araştırmaya Türk kütüphanecilik ve bilgi yönetimi literatüründe yer alan kullanıcı araştırmalarının nicelik ve niteliğinin saptanması amacıyla başlanmış, kullanıcı araştırması niteliğinde araştırma sayısının çok az sayıda olması, ancak kullanıcı ile ilgili dolaylı veri ve görüşleri veren yazıların varlığı nedeniyle çalışmanın kapsamı genişletilmiştir. Bu nedenle doğrudan veya dolaylı olarak kullanıcı faktörüne yer veren yazı ve tezler çalışma kapsamına alınmıştır. Bu amaçla kütüphanecilik bölümleri ve Yükseköğretim Kurulu Yayın ve Dokümantasyon Dairesi Başkanlığı Tez Merkezinden erişilen 239 tez ile alanımızın mesleki süreli yayınları olan TKDB, Türk Kütüphaneciliği ve Bilgi Dünyası dergilerinin tüm sayıları incelenmiştir. TKDB'nin 1987'ye kadar hakemli bir dergi olmaması nedeniyle, çalışma kapsamına duyurular dışında hakemli hakemsiz tüm yazılar dâhil edilmiştir. Yayın hayatına 2000 yılında hakemli bir dergi olarak başlamasına rağmen Bilgi Dünyası dergisi kapsamında yer alan hakemsiz makaleler de çalışmanın bütünlüğü açısından araştırma kapsamına alınmıştır. TKDB'nin 1952-1986 yıllarında ve aynı yayının devamı niteliğinde olan Türk Kütüphaneciliği dergisinin 1987-2006 yıllarında yer alan toplam 1690 makale ile Bilgi Dünyası'nın 20002006 yılları arasında yayımlanan 98 makale olmak üzere toplam 1788 makale araştırmamız kapsamında değerlendirilmiştir. İncelenen tez ve makalelerin konuya yaklaşım, ele alınan kullanıcı grubu, (varsa) yöntem ve veri toplama teknikleri gibi farklı açılardan içerik analizleri yapılmıştır.

\section{Kullanıcılarla İlgili Tezler}

Türkiye'de Ankara Üniversitesi, Atatürk Üniversitesi, Başkent Üniversitesi, Hacettepe Üniversitesi ve İstanbul Üniversitesi olmak üzere beş üniversitede "Bilgi ve Belge Yönetimi" bölümü vardır. 1954 yılında kurulmuş olan Ankara Üniversitesi Bilgi ve Belge Yönetimi Bölümünde 1958 yılından bu yana doktora düzeyinde, 1976 yılından itibaren de yüksek lisans düzeyinde tez hazırlanmaktadır (Atılgan ve Türkan, 1995). İstanbul Üniversitesi Bilgi ve Belge Yönetimi Bölümü 1963 yılında kurulmuş ve ilk tez çalışması 1967 yılında doktora düzeyinde yapılmıştır (Keseroğlu, 
1987). İstanbul Üniversitesi Bilgi ve Belge Yönetimi Bölümünde yüksek lisans tezleri 1985 yılından itibaren yapılmaya başlanmıştır (Uraz, 1995). Hacettepe Üniversitesi Bilgi ve Belge Yönetimi Bölümü 1972 yılında yüksek lisans eğitimi amacıyla kurulmuş, 1974 yılında yüksek lisansın yanı sıra lisans eğitimi de vermeye başlamıştır. Bu üniversitede 1974 yılında ilk doktora tezi, 1975 yılında ise ilk yüksek lisans tezi tamamlanmıştır (Çakın, 1997). Bu üç bölümde yüksek lisans ve doktora tez çalışmalarının sayıları artarak devam etmektedir. 1995 yılında kurulan Atatürk Üniversitesi Kütüphanecilk Bölümü ile 2002 yılında kurulmuş olan Başkent Üniversitesi Bilgi ve Belge Yönetimi Bölümünde henüz tamamlanmış tez yoktur.

Uçak'ın (2004) bu bölümlerde 2002 yılına kadar bitirilen tezler üzerinde yaptığı çalışma, bu konuda bir profil elde etmemize yardımcıdır. Bu araştırmada alanımızda yapılan 206 tezin 33'ünün doğrudan veya dolaylı olarak kullanıcılarla ilgili olduğu saptanmıştır. Kullanıcı araştırması içeren tezler yapıldıkları yıl, bölüm, derece, yöntem, veri toplama tekniği, model ve kullanıcı grubu açısından incelenmiştir. Bu çalışmayı bugüne taşımak amacıyla, 2003-2006 yılları arasında yapılan tezler Yükseköğretim Kurulu Yayın ve Dokümantasyon Dairesi Tez Merkezinden ve ilgili bölümlerden araştırılarak son dört yıllık sürede bitirilmiş 33 tez bu sayıya eklenmiş ve toplam 239 teze ulaşılmıştır. Son dört yılda eklenen 33 tezin 9'unun kullanıcılarla ilgili olduğu anlaşılmıştır. Bu 9 tez de eklendiğinde, bugüne kadar kullanıcılarla ilgili olarak yapılan tez sayısı 42'ye ulaşmaktadır. Bu sayı bütün tezlerin \%17,57'sini oluşturmaktadır. Söz konusu 42 tezin konuya, yıllara ve derecelere göre dağılımı, konuya yaklaşımları, incelenen kullanıcı grupları, kullanılan araştırma yöntemleri ve veri toplama teknikleri açısından değerlendirilmesi aşağıdadır.

\section{Yıllara ve Derecelere Göre Dağılım}

Kullanıcı görüşlerine yer veren ilk tez 1976 yılında Hacettepe Üniversitesinde yüksek lisans tezi olarak bir bilgi merkezi tasarımında kullanıcıların beklenti ve gereksinimlerini saptamak üzere yapılmıştır. 1976 yılından 1990 yılına kadar yapılan tezlerde kullanıcı görüş ve beklentilerine yer veren tez sayısı 5 adettir. 1990 
yılından sonra bu sayının giderek arttığı görülmektedir. 1990 yılından 2006 yılının sonuna kadar ise bu sayı 37'ye ulaşmıştır. Kullanıcılarla ilgili toplam 42 tezin \%88'ini, 1990 sonrası yapılan tezler oluşturmaktadır. 1990-2000 yılları arasında 22, 2000-2006 yılları arasında ise 15 tez kullanıcılarla ilgilidir. Toplam 42 tezin 33'ü (\%78) yüksek lisans, 9'u (\%21) ise doktora düzeyindedir.

\section{Konuya Yaklaşım}

Çalışma kapsamındaki tezlerin büyük çoğunluğunda araştırmanın sistem merkezli olarak tasarlandığı anlaşılmaktadır. İncelenen 42 tezin 29'u (\%69) kullanıcıları bir bilgi merkezi veya sistemi ile ilişkilendirerek araştırmaktadır. Bu çalışmalarda, ya verilen bir hizmetin kullanım oranı ya da belli kaynakların tercih edilme oranları gibi bir sistem veya kaynağın kullanımına yönelik değerlendirme araştırmalarının bir parçası olarak kullanıcı görüşlerine yer verildiği görülmektedir. Tezlerden sadece 13 tanesi (\%31) kullanıcının gereksinim ve davranışlarını belli bir merkez, sistem veya kaynağa bağlı olmadan belirlemek amacıyla konuyu ele almaktadır.

\section{İncelenen Kullanıcı Grupları}

Tezler inceledikleri kullanıcı gruplarına göre sınıflandııılı̆̆ında, 42 tezden 17'sinin (\%40) akademisyenlerle ilgili olduğu anlaşılmaktadır. Bunu 6'sı $(\% 14,2)$ genelde kütüphaneler ya da halk kütüphaneleri ve 4'ü $(\% 9,5)$ çocuklar üzerine yapılan tezler izlemektedir. Orta öğrenim öğrencileri 3 , üniversite öğrencileri 3 ve özel kurum çalışanları ile ilgili olarak 3 tez yapılmıştır. İkişer tez ile hekimler, özürlüler/hastalar ve sanayi çalışanları, üzerinde en az çalışılan kullanıcıları oluşturmaktadır.

\section{Araştırma Yöntemi ve Veri Toplama Teknikleri}

İncelenen 42 tezin 35 'inde (\%83) betimleme yönteminin kullanıldığı görülmektedir. Betimleme ve bibliyometri yöntemini kullanan bir, karşılaştırmalı tekniği kullanan bir araştırmacı vardır. Bir tezde içerik analizi, 2 tezde deneysel yöntem tek başına kullanılırken, son yapılan doktora tezlerinin bir tanesinde deneysel yöntem içerik analizi ile birlikte kullanımıştır. Tüm tezler içinde sadece birinde 
nitel yöntem kullanıldığı, iki tezde ise hem nitel hem de nicel yöntemlerden yararlanıldığı anlaşılmaktadır.

Yapılan tezlerden $20(\% 47)$ tanesinde veri toplama tekniği olarak sadece anket tekniği kullanılmıştır. Ancak bunun dışında anket tekniğinin diğer tekniklerle birlikte kullanıldığı tezler de vardır. Nitekim $5(\% 11,9)$ tezde anket ve görüşme; $4(\% 9,5)$ tezde anket ve gözlem; $6(\% 14,2)$ tezde anket, görüşme ve gözlem; bir tezde anket ve sözlü protokol; bir tezde anket gözlem ve sözlü protokol, bir tezde de anket ve log analizinin birlikte kullanıldığını görmekteyiz. Bu çalışmaları da dâhil ettiğimizde anket tekniğinden yararlanan tez sayısı 38'e $(\% 90,4)$ çıkmaktadır. Bunun yanı sıra sözlü protokol olarak da bilinen yüksek sesle düşünme (think aloud) tekniğini tek başına kullanan ve görüşme ve sözlü protokol tekniğini birarada kullanan birer adet tez vardır.

\section{Kullanıcılarla İıgili Makaleler ve Diğer Yazılar}

Kütüphanecilik ve bilgi yönetimi alanının önemli süreli yayınları olan Türk Kütüphaneciliği ve Bilgi Dünyası dergileri başlangıç sayılarından bu yana ele alınmış ve kullanıcılarla ilgili yazılar saptanarak incelenmiştir.

\section{TKDB ve Türk Kütüphaneciliği}

Yayın hayatına 1952 yılında Türk Kütüphaneciler Derneği Bülteni (TKDB) olarak başlayan ve alanımızın ilk mesleki süreli yayını olan dergi, 1987 yılında Türk Kütüphaneciliği adını almıştır. Bu yıla kadar hakemsiz olan derginin, bu tarihten sonra hakemli olduğunu ve yazıların hakemli ve hakemsiz yazılar olarak gruplandırılarak yayımlandığını görüyoruz. Gerekli bütünlüğün sağlanabilmesi için duyuru ve haberler dışında kalan hakemli ve hakemsiz tüm yazılar çalışma kapsamına alınmıştır. Çalışmamız sonucunda TKDB ve Türk Kütüphaneciliği dergilerinde 1952-2006 yılları içinde toplam 1690 yazının yayımlandığı, bunlardan sadece 41'inde kullanıcı / okuyucu faktörüne yer verildiği saptanmıştır. Bir başka deyişle, 55 yıllık sürede bu dergide yer alan yazıların sadece \%2,4'ünün kullanıcılarla ilgili olduğunu söyleyebiliriz. Bu yazıların konuya yaklaşımlarına, kullanıcı gruplarına, yıllara, kullanılan yöntem ve veri toplama tekniklerine göre dağılımları şu şekildedir: 
Yıllara göre yazıların dağılımı: $\mathrm{Bu}$ araştırmada, TKDB ve Türk Kütüphaneciliği'nde 55 yıllık sürede yayımlanan yazılar onar yıllık zaman dilimleri içinde ele alınıp incelenmiştir. Bu inceleme sonucunda TKDB'de 1952-1961 yıllarını kapsayan ilk on yıllık sürede 261 yazı yer almasına rağmen, bunlardan hiç birinin kullanıcılarla ilgili bilgi ve görüş içermediği görülmektedir. Derginin 1962-1971 yılları arasında ise toplam 279 yazı yayımlanmış ve bunlardan 3 tanesinde kullanıcılarla ilgili veri ve görüşlere yer verilmiştir. Bunlardan ilki 1964 yılında "Halk kütüphanelerinde neler okunmaktadır?" başlığı altında yayımlanmıştır. Bu yazıda okuyucu istatistiklerine dayanılarak halk kütüphanelerinde en çok okunan kitapların bir listesinin oluşturulmasına çalışılmıştır. Bir sonraki yazı, Danimarka'da gençlerin okuma alışkanlıklarını inceleyen bir makalenin çevirisi olarak 1970 yılında yayımlanmıştır. Bu on yıllık dönemdeki son yazı, 1971 yılında yayımlanan okuyucu eğitimi hakkında yazılmış kuramsal bir yazıdır.

1972-1981 yılları arasında toplam 252 yazı yayımlanmış ve yine 3 tanesinde kullanıcılara yer verilmiştir. Bunlardan ilki 1979 yılında, anaokuluna giden çocukların resimli kitaplar hakkındaki görüşlerini araştıran bir yazıdır. Yüz çocuk üzerine yapılan bu özgün araştırma, kütüphanecilik dışında çalışan bir araştırmacı tarafından gerçekleştirilmiştir. Bu dönemdeki ikinci ve üçüncü yazılar 1980 yılında yayımlanmıştır. Bunlardan ilki üst düzey yöneticilerin kütüphane algısını araştıran özgün bir araştırmadır. Diğer yazı ise kütüphane okuyucusunun eğitilmesinin önemi üzerine hazırlanmış kuramsal bir makaledir.

1982-1991 yılları arasında dergide yer alan yazı sayısı toplam 290'a ulaşırken, kullanıcılara yer veren yazı sayısı da 8'e yükselmiştir. 1984 yılında 3; 1985, 1988 ve 1989 yıllarında birer; 1990 yılında 2 yazıda kullanıcı faktörüne yer verilmiştir. Bu yazılardan ilki 1973 yılında 1446 gezici kütüphane kullanıcısı üzerine yapılan, ancak 1984 yılında yayımlanan bir araştırmadır. 1984 yılında yayımlanan ikinci yazı Cebeci Halk Kütüphanesini kullanan yetişkinler üzerine yapılan bir araştırmadır. Aynı yıl cezaevlerinde kütüphane hizmetlerinden yararlanan kullanıcıları konu alan bir başka özgün araştırma da yayımlanmıştır. 1985 yılında yapılan bir başka araştırmada Millî Kütüphane kullanıcıları 
incelenmiştir. 1988 yılında gençlerin okuma davranışları literatüre dayalı olarak değerlendirilmiş; 1989 yılında 32 anaokulu çocuğunun, resimli kitaplarda yer alan resimlere tepkisi bir araştırmayla incelenmiştir. 1990 yılında üniversite öğrencilerinin okuma alışkanlıkları ve "Niçin az okuyoruz?" adlı kamuoyu araştırması sonuçlarını değerlendiren iki yazı yer almıştır.

Türk Kütüphaneciliği'nde 1992-2001 yılları arasında yer alan toplam yazı sayısı ile birlikte kullanıcılarla ilgili yazıların sayısında da büyük artış olduğu görülmektedir. 1992-2001 yılları arasında adı geçen dergideki hakemli-hakemsiz toplam yazı sayısı 451'dir. Bu yazıların 19'unda kullanıcı faktörüne yer verilmiştir. Bunlardan ilki 1990 yılında üniversite kütüphanelerinde kütüphaneci-kullanıcı etkileşimini literatüre dayanarak açıklayan bir çalışmadır. Bu yazıyı 1993 yılında İngiliz Kültür Heyeti Ankara Kütüphanesi okuyucularının çevrimiçi katalog kullanımına ilişkin görüşlerini araştıran bir yazı ile anaokulu öğretmenlerinin çocuk kitaplarına ilişkin görüşlerini saptamaya çalışan bir yazı izlemektedir. 1995 yılında, Ankara halkının okuma alışkanlığı konusunda ve teze dayalı kapsamlı bir araştırma dergide yayımlanmıştır. Aynı araştırmanın bir başka boyutuyla 1996 yılında da dergide yer aldığını görüyoruz. 1997 yılında bilgi gereksinimi ve bilgi arama davranışları ile bunları etkileyen nedenleri ele alan kuramsal bir yazının; 1998 yılında tekstil endüstrisinde yer alan firmalarda bilgi gereksinimini saptamaya yönelik bir doktora tezinin sonuçlarının; 1999 yılında DTCF Kütüphanesi kullanıcılarının kütüphanenin hizmet kalitesine ilişkin görüşlerini araştıran bir çalışmanın yayımlandığını görüyoruz. 2000 yılının kullanıcılarla ilgili yazıların dergide en fazla yer bulduğu yıl olduğu anlaşılmaktadır. 2000 yılında 7 yazıda kullanıcılardan söz edilmektedir. Bunlardan ilk üçü farklı kullanıcı gruplarının internet kullanımıyla ilgili literatüre dayalı ve kuramsal çalışmalardır. Diğer iki çalışma, çocukların okuma alışkanlıkları üzerine literatür araştırmalarına dayanan yazılardır. 2000 yılının son iki yazı ise müşteri memnuniyeti ve bilgi kullanımında insan ögesinin önemine değinen kuramsal çalışmalardır. 2001 yılında yayımlanan kullanıcılarla ilgili yazıların ilki engelli kullanıcıların bilgiye erişimi ve buna katkı sağlayacak unsurların ele alındığı kuramsal bir çalışmadır. Bunu öğretim üyelerinin danışma 
kütüphanecileri açısından önemini inceleyen yabancı bir yazının çevirisi izlemektedir. Aynı yıl Kütüphanecilik Bölümü öğrencilerinin okuma alışkanlıkları üzerine gerçekleştirilen bir araştırma ile çocukların internet kullanımı ve konuyla ilgili yasaları literatüre dayanarak değerlendiren bir yazı yer almaktadır.

2002- 2006 yılları son beş yıllık dönemi kapsamakta ve bu sürede yayımlanan hakemli ve hakemsiz toplam 157 yazının 8'ini kullanıcı ile ilgili yazılar oluşturmaktadır. Bunlardan ilki bir önceki yıl yayımlanan Kütüphanecilik Bölümü son sınıf öğrencileri üzerine yapılan çalışmanın devamıdır. Bu yazıyı ilköğretim öğrencileri ve öğretmenlerinin bilgi okuryazarlığı üzerine yapılan iki araştırma yazısı izlemektedir. 2002'de yayımlanan son yazı ise ilköğretim öğretmenlerinin okuma ve halk kütüphanelerini kullanma alışkanlıklarını araştırmaktadır. 2003 ve 2004 yıllarında kullanıcıları konu alan hiçbir yazıya rastlanılmazken; 2005 yılında üniversite öğrencilerinin bilgi okuryazarlığı becerilerindeki zorlanma düzeylerini araştıran teze dayalı bir yazı ile kullanıcı hakları konusunda deneme niteliğinde bir yazı bulunmaktadır. Son olarak 2006 yılında kullanıcıların bilişsel yapılarının bilgi arama davranışları üzerine etkisini kuramsal olarak irdeleyen bir yazı ile bilgi merkezlerinde kullanıcıya bakış açısını hicveden deneme niteliğinde bir yazı yayımlanmıştır.

Kullanıcı türü, yaklaşım ve yöntem açısından yazıların değerlendirilmesi: TKDB ve Türk Kütüphaneciliği'nde kullanıcıları konu alan 41 yazının büyük bir kısmını halk ve halk kütüphanelerinin kullanıcıları oluşturmaktadır. Bunu sırasıyla üniversite öğrencileri, okul öncesi ve ilkokul öğrencileri, akademisyenler ve ilkokul öğretmenleri üzerine yazılan yazılar izlemektedir. Genel kapsamlı yazıların yanı sıra, engelliler, endüstri alanında çalışanlar veya yöneticileri konu alan yazılar da dergide yer almaktadır.

Yazıların büyük bir kısmı kullanıcıları belli bir sistemle ilişkilendirerek ele almaktadır. Kullanıcıyı sistemden bağımsız ele alan yazı sayısı çok azdır. Araştırmaya dayalı olarak hazırlanan yazıların tamamında nicel yöntemler kullanılmıştır. Betimleme yöntemi (18 yazıda) ilk sırada tercih edilirken, bunu deneysel 
yöntem (4 yazı) izlemektedir. Yazıların büyük bir kısmı kuramsal ve literatür değerlendirmesine dayanmaktadır (14 yazı). Bunun yanı sıra üç yazının çeviri ve 2 yazının da deneme niteliğinde olduğu görülmektedir.

Veri toplama tekniği olarak en fazla anket tekniğinin (15) kullanıldığı; bunu az sayıda kullanılan görüşme ve gözlem tekniklerinin izlediği; bazı araştırmalarda okuyucu istatistiklerinin değerlendirildiği anlaşılmaktadır.

\section{Bilgi Dünyası}

Kullanıcı araştırmaları açısından ülkemizde kütüphanecilik ve bilgibilim alanında yayımlanan ikinci önemli yayın olan Bilgi Dünyası dergisi için de durum farklı değildir. Bu derginin yayımlanmaya başladığı 2000 yılından bu yana yılda iki sayı olmak üzere toplam 14 sayısı yayımlanmıştır. Dergide 2000-2006 yılları arasında 58'i hakemli olmak üzere toplam 98 makale yayımlanmıştır. $\mathrm{Bu}$ makaleler içinde sadece 3 tanesinde kullanıcılarla ilgili veri ve görüşlere yer verilmektedir. Kullanıcılarla ilgili makalelerin 2000-2006 yılları arasında yayımlanan tüm makalelere oranı \%3'tür.

Bu makalelerden ilki 2000 yılında, ilköğretim öğrencilerinin okuma alışkanlıklarını ölçmek amacıyla yapılmıştır. İkinci çalışma 2004 yılında yayımlanmıştır ve öğrenci velilerinin okuma ve halk kütüphanesi kullanma alışkanlıklarını konu almaktadır. Üçüncü çalışma ise 2006 yılında yayımlanmıştır. Bu son çalışmada üniversite öğrencileri araştırma konusu olarak ele alınmakta ve öğrencilerin kitap seçiminde etkili olan biçimsel faktörlerin betimlenmesine çalışılmaktadır. Kullanıcı görüşlerine yer veren bu üç araştırma da hakemli yazılar kısmında yer almaktadır. Her üç makalede de betimleme yöntemi kullanılmıştır. Anket tekniğinin üç makalede de veri toplama tekniği olarak tercih edildiği; makalelerden birinde anket ve görüşme tekniklerinin birarada kullanıldığı anlaşımaktadır. Makalelerin hepsinde kullanıcı bir bilgi sistemi ile ilişkilendirilerek ele alınmıştır. 


\section{Değerlendirme ve Sonuç}

Kütüphanecilik ve bilgi yönetimi alanında yapılan 239 tezin \%17,57'si ve 1788 makalenin \%2,4'ü doğrudan veya dolaylı olarak kullanıcılarla ilgilidir. Elde edilen veriler ülkemizde bu konuda ilk çalışmaların 1970'li yıllarda başladığını ve 1990 sonrası artış kaydettiğini göstermektedir. Kullanıcılarla ilgili tezlerin \%88'i 1990 sonrasında yapılmıştır. İncelenen tezlerden, kullanıcı anlayışının daha çok bir merkez ve sistemi kullanan aktif kullanıcı ile sınırlı kaldığı anlaşıımaktadır. Değerlendirilen tezlerin \%69'u var olan sistem ve hizmetlerin işleyişini ve kullanılırığını sınamak amacıyla kullanıcı görüşlerine yer veren çalışmalardır. Bilgi gereksinimi, bilgi arama ve kullanma davranışı, bunları etkileyen nedenler, kullanıcı grupları arasındaki farklılıklar inmal edilen konulardır. Bu çalışmalarda daha çok var olan durum veya sorunun tanımlanabilmesi esas alındığı için, kullanıcının birey olarak bilgiyle ilişkisi ve bunu etkileyen nedenler yeterince sorgulanmamıştır. Sorunun bu şekilde ele alınıyor olması araştırma yöntemi seçimini de etkilemektedir. Araştırmalarda en çok betimleme yöntemi kullanılırken, anket en çok tercih edilen veri toplama tekniği olmuştur. Çalışma kapsamında incelenen tezlerin \%83'ünde betimleme yöntemi kullanılmıştır. 2000 yılı sonrası yapılan üç tezde nitel yöntemlerden yararlanılmış olması, sayılardaki artışla birlikte konuya yaklaşım ve buna uygun yöntem seçiminde de yeni arayş̧lar olduğunu göstermektedir. Tezlere konu olan kullanıcı grupları içinde en çok akademisyenler üzerinde araştırma yapıldığı görülmektedir. İncelenen 42 tezin \%40'ı akademisyenleri konu almaktadır. Bu grubu ikinci sırada halk kütüphanelerinin kullanıcıları, üçüncü sırada çocuklar izlemektedir.

İncelediğimiz süreli yayınlarda 1971 yılına kadar hiç bir makalede kullanıcı faktörü yer almazken, 1980'li yıllarda konuya ilginin arttığı, 1990 sonrası ise kullanıcıları konu alan makale sayısında önceki yıllara oranla daha büyük artış olduğu görülmektedir.

Her üç dergide yer alan toplam 44 makaleden 14'ü $(\% 31,8)$ halk ve genel kapsamlı olarak kullanıcıları ele alırken, 9'u (\% 20,4) üniversite öğrencilerini kullanıcı grubu olarak ele almakta, bunu 5 
makale ile (\%11) okul öncesi çocuklar, 4 makale ile eşit oranda (\%9) akademisyenler ve ilköğretim öğrencileri izlemektedir. Bu sonuçlara göre tüm öğrenci grupları $\% 40,4$ oranıyla üzerinde en çok çalışılan grubu oluşturmaktadır. En az üzerinde çalışılan gruplar ise engelliler ve yöneticilerdir. Bazı meslek gruplarının ise hiç ele alınmadığı görülmektedir.

Çalışılan konu açısından baktığımızda, bilgi okuryazarlığı ve okuma alışkanlığı gibi konuların ağırlıklı olarak incelendiği, son yıllarda ise İnternet kullanımı üzerine yapılan araştırmaların sayısında artış olduğu anlaşıımaktadır. Tezlerde olduğu gibi makalelerde de en çok betimleme yönteminin (21 yazı) tercih edildiği, bunu deneysel yöntemin (4 yazı) izlediği belirlenmiştir. Ancak pek çok makale özgün bir araştırmaya dayanmadığı için konuyla ilgili literatür değerlendirmesi (16 yazı) niteliğindedir. Bunun yanı sıra çeviri ve deneme niteliğinde yazılar da literatürde yer almaktadır. Ayrıca araştırmaya dayalı makalelerde anket ve görüşme tekniklerinin en fazla tercih edilen veri toplama teknikleri olduğu da sonuçlardan anlaşılmaktadır.

Elde edilen bulgular, dünya literatürüyle karşılaştırıldığında, ülkemizde "bilgi gereksinimi", bilgi arama davranışları", "bilgi kullanım özellikleri", "kullanıcı grupları ve özellikleri" gibi konuların yeterince ele alınmadığını görülmektedir. Araştırmalarda üzerinde yoğunlukla çalışılan grupların ülkemizde ve yurt dışında akademisyenler ve öğrenciler olarak ilk sırada yer aldığı ve seçilen yöntemlerin ise benzerlik gösterdiği anlaşılmaktadır. Ancak yurt dışında yapılan çalışmalarda, çok daha farklı kullanıcı gruplarının giderek daha çok nicel ve nitel yöntemler birarada kullanılarak araştırıldığı görülmektedir. Ayrıca dünyada 1990 sonrası bilgi davranışlarını etkileyen nedenler üzerinde sıklıkla çalışılmakta olduğu, bu araştırmalarda konunun disiplinler arası boyutuyla ele alındığı bilinmektedir. Yapılan çalışmaların sistemden bağımsız olarak ele alınması, çalışmalarda aktif kullanıcıların yanı sıra pasif kullanıcıların da dikkate alınması araştırma sonuçlarının uygulamaya etkisini artırmaktadır.

Sonuç olarak Türkiye'de yapılan kullanıcı araştırmalarının ülkenin kullanıcı profilini oluşturmada yeterli sayı ve nitelikte 
olmadığını söyleyebiliriz. Bu sonucun hizmetleri tasarlarken ve değerlendirirken bu hizmetlerin kimin için tasarlandığının dikkate alınmaması ile yakından ilgisi vardır. Kullanıcı unsurunun önemsenmesi kadar bu alanda yapılacak araştırmaların sonuçlarının uygulamaya aktarılabilmesi de önemlidir. Bu nedenle yapılacak araştırmalar öncesinde yaklaşımın belirlenmesi, problemin saptanması ve buna uygun yöntemin seçilmesi gerekmektedir. Wilson'a (2000) göre kullanıcı, pek çok iletişim ve bilgi süreci içinde tanımlanabilir. Bu nedenle herhangi bir kullanıcı araştırması planlamadan önce kullanıcıyı bir grubun üyesi olarak $\mathrm{mI}$; bir ürünün, hizmetin alıcısı olarak $\mathrm{ml}$; yoksa herhangi bir nedenle bilgi arayan bir birey olarak mı tanımladığımız çok önemlidir. Bu tanımlama konuya ne açıdan yaklaştığımız kadar, nasıl incelememiz gerektiğini göstermesi açısından da gereklidir.

\section{Kaynakça}

Atılgan, D. ve Türkan, Ç. (1995). A.Ü. DTCF Kütüphanecilik Bölümünde yapılan doçentlik, doktora, master ve Emily Dean ödülü alan lisans tezleri bibliyografyası, Türk Kütüphaneciliği, 9, 439-447.

Bates, M.J. (2000). Bates' bibliography of works on information seeking, indexing, and information retrieval system design. 5 Aralık 2006 tarihinde http://www.gseis.ucla.edu/faculty/bates/bib-intro.html adresinden erişildi.

Bouazza, A. (1989). Information user studies. Encyclopedia of library and information science içinde (cilt 44, ek 9, s. 144-164). New York: Dekker.

Case, D.O. (2002). Looking for information: a survey of research on information seeking, needs, and behavior. London: Academic Press.

Çakın, İ. (1997). 25. Yılında Hacettepe Üniversitesi Kütüphanecilik Bölümü. B. Yılmaz (Yay. haz.), Kütüphanecilik Bölümü 25. Yıl’a Armağan içinde (s.7-31). Ankara: Hacettepe Üniversitesi.

Çapar, B. (1990). Kullanıcı incelemeleri. D. Atılgan ve F. Özdemirci (Yay. haz..), Türk Kütüphaneciler Derneği 40. Yıl Kütüphanecilik Kurultayı (30 Kasım-1 Aralık 1989, Ankara) içinde (s. 161-164). Ankara: TKD. 
Jarvelin, K. ve Vakkari, P. (1990). Content analysis of research articles in library and information science. Library \& Information Science Research, 12, 395-421.

Julien, H. (2000). A longitudinal analysis of the information needs and uses literature. Library \& Information Science Research, 22, 291-309.

Keseroğlu, H. (1987), İstanbul Üniversitesi Edebiyat Fakültesi Kütüphanecilik Bölümü öğretim elemanlarının yayınları ile doktora, doçentlik, profesörlük çalışmaları, bitirme tezleri 1967-1984. Kütüphanecilik Dergisi: Belge Bilgi Kütüphane Araştırmaları, 1, 187-218.

Menzel, H. (1966). Information needs and uses in science and technology. C.A. Cuadra ve A.W. Luke (Ed.), Annual Review of Information Science and Technology içinde (cilt 1, s. 41-69). Chicago: Encyclopedia Britannica.

Ötüken, A. (1961). Türk kütüphaneciler Derneği Bülteni on yıllık tahlili indeksi. Türk Kütüphaneciler Derneği Bülteni, 2, 163-165.

Paisley, W.J. (1968). Information needs and uses. C.A. Cuadra (Ed.), Annual Review of Information Science and Technology içinde (cilt 3, s. 1-30). Chicago: Encyclopedia Britannica.

Prytherch, R. (Derl.). (1995). Harrod's librarians' glossary (8th ed.). Aldershot: Gower.

Tonta, Y. (2002). Türk Kütüphaneciliği dergisi, 1987-2001. Türk Kütüphaneciliği, 16, 282-320.

Uçak Özenç, N. (2001). Kullanıcı araştırmalarının sorunları. T. Fenerci ve O. Gürdal (Yay. haz), 21. Yüzyıla Girerken Enformasyon Olgusu, Ulusal Sempozyum Bildirileri 19-20 Nisan 2001, Hatay içinde (s. 207214). Ankara: TKD.

Uçak Özenç, N. (2004). User studies in Turkey: an evaluation of dissertations. Information Development, 20, 122-129.

Uraz, N. (1995). İstanbul Üniversitesi Edebiyat Fakültesi Kütüphanecilik Bölümünde yapılan tez çalışmaları: 1985-1994. Türk Kütüphaneciliği, 9, 170-172. 
Wilson, T.D. (1981). On user studies and information needs. Journal of Documentation, 37, 3-15.

Wilson, T.D. (2000). Recent trends in user studies: action research and qualitative methods. Information Research, 5(3), 1-38. 24 Aralık 2006 tarihinde http://informationr.net/ir/5-3/paper76.html adresinden erişildi.

Yontar, A. (1995). Main research problems being investigated in Turkey as revealed in graduate theses. Booklet 7, Division of Education and Research, 61st IFLA Council and General Conference, Istanbul, Turkey, August 20-26, 1995 içinde (s. 38-47). İstanbul: IFLA.

Yontar, A. ve Yalvaç, M. (2000). Problems of library and information science research in Turkey: a content analysis of journal articles 1952-1994. IFLA Journal, 26, 39-46. 